Article (refereed) - postprint

Curtis, R.J.; Botham, M.S.; Brereton, T.M.; Isaac, N.J.B. 2015. The rise and demise of the Glanville fritillary on the Isle of Wight. Journal of Insect Conservation, 19 (2). 305-311. 10.1007/s10841-014-9737-2

(C) Springer International Publishing Switzerland 2014

This version available http://nora.nerc.ac.uk/509084/

NERC has developed NORA to enable users to access research outputs wholly or partially funded by NERC. Copyright and other rights for material on this site are retained by the rights owners. Users should read the terms and conditions of use of this material at http://nora.nerc.ac.uk/policies.html\#access

This document is the author's final manuscript version of the journal article, incorporating any revisions agreed during the peer review process. Some differences between this and the publisher's version remain. You are advised to consult the publisher's version if you wish to cite from this article.

The final publication is available at Springer via http://dx.doi.org/10.1007/s10841-014-9737-2

Contact CEH NORA team at noraceh@ceh.ac.uk

The NERC and CEH trademarks and logos ('the Trademarks') are registered trademarks of NERC in the UK and other countries, and may not be used without the prior written consent of the Trademark owner. 


\section{The Rise and Demise of the Glanville fritillary on the Isle of Wight.}

Authors: Curtis, R.J. ${ }^{1,2,3,4}$, Botham, M. ${ }^{1}$, Brereton, T.M. ${ }^{5}$ \& Isaac, N.J.B. ${ }^{1}$

${ }^{1}$ NERC Centre for Ecology \& Hydrology, Maclean Building, Crowmarsh Gifford, Wallingford, OX10 8BB, UK

${ }^{2}$ University College London, Gower Street, London, WC1E 6BT, UK

${ }^{3}$ Institute of Zoology, Zoological Society of London, Regent's Park, London, NW1 4RY, UK

${ }^{4}$ Present address: Environment and Sustainability Institute, University of Exeter, Penryn Campus Penryn, Cornwall TR10 9FE, UK

${ }^{5}$ Butterfly Conservation, Manor Yard, East Lulworth, Wareham, BH20 5QP

Keywords: Melitaea cinxia, metapopulation, extinction, abundance, habitat quality, temperature, butterflies.

\section{Abstract}

The Glanville fritillary is one of Britain's rarest breeding butterflies, and is predominantly restricted to the south coast of the Isle of Wight. Populations have been monitored annually at a high proportion of known sites by counting the number of larval 'webs' during spring since 1996.

In this paper, we present population time series for eight core sites. Populations have been observed to fluctuate considerably over the last 18 years, with a high degree of synchrony between sites. Recently, numbers of larval webs have shown a severe decline, with simultaneous extinctions occurring across many former strongholds.

We combine our web count data with counts of adult butterflies from five sites of the UK Butterfly Monitoring Scheme. Together, these data suggest that the Glanville Fritillary is threatened by extinction on the Isle of Wight, and that the total area used for breeding is likely no more than a few $k m^{2}$. 
The results flag up the need for a national census of remaining populations and further research to understand causes of decline, so that a conservation recovery plan can be developed.

\section{Introduction}

The abundance and distribution of a species is a reflection and response to environmental conditions (Brown 1984). All species populations fluctuate in response to environmental changes over time (Andrewartha \& Birch 1954), and the direction and scale of the response can be influenced by many factors, for example, climate, resources, predators and diseases and often the complex interactions between them (Begon et al. 1986). Clarifying the importance of the various factors that determine species distributions and abundance is a key question in ecology (Whittaker 1975; MacArthur 1984), as although there are general patterns, the mechanistic explanations do not yet appear to be definitive (Storch \& Gaston 2004; McGill 2006; Mattila et al. 2011). However, there are key drivers of these processes, and temperature and resource availability influence both the distribution and abundance of nearly all species (May 1975; Krebs 1978).

Like most ectothermic insects, butterflies are extremely sensitive to changes in temperature and restricted by both climatic restraints (Thomas 1995; Bryant et al. 2002; Davies et al. 2006) and limitations in resources (Dennis 2010). The high degree of specialisation required to successfully utilise both differing temperature gradients and resources within the smallest habitats means that many butterflies are short lived thermophilous species, often showing rapid and clear responses to changes in the environment making them ideal indicators to gauge the health of habitats and ecosystems (Erhardt \& Thomas 1991; Oostermeijer \& van Swaay 1998; Thomas et al. 2004). Indeed, they have long attracted population biologists as convenient model organisms (Ford 1945; Ehrlich 1983), and are one of the few insect groups for which annual abundance monitoring is possible (Roy et al. 2007).

The Glanville fritillary Melitaea cinxia is one of the most intensively studied butterfly species in the world. In Finland, long-term dynamics have been monitored within a large network of 4000 habitat patches in the Åland Islands since 1991 (Ojanen et al. 2013). This research has focussed on the role of patch size, shape and isolation on the persistence of individual populations (Hanski 1994, 1999). The insights from the Åland Islands have been influential in the development of metapopulation theory ( $\underline{\text { Hanski 1998) }}$ and its extensions to biodiversity conservation in fragmented landscapes (Ross et al. 2008; Johst et al. 2011; Jones 2011; Leidner \& Haddad 2011).

In the U.K., Glanville fritillary females are highly selective in their egg-laying preferences, choosing to oviposit only on small hostplants in warm microclimates (Thomas et al. 2001). The availability of 
Plantago lanceolata, the hostplant, in this suitable condition is a convenient measure of habitat quality that explains much of the variation in occupancy and abundance between sites (Thomas et al. 2001). Within sites, both habitat quality and spring temperature are strongly correlated with population dynamics, with dramatic population increases in warm years corresponding with a good supply of plantains in suitable condition (Curtis \& Isaac 2014).

In Britain, Glanville fritillaries are largely restricted to early-successional habitat on south-facing slopes on the Isle of Wight, although in the $19^{\text {th }}$ century it was more widespread and occupied several sites on the mainland (Asher et al. 2001). It is univoltine and monophagous, with a typical flight period lasting from May to July. Eggs are laid in clusters on the underside of Ribwort plantain (Plantago lanceolata) leaves, with most oviposition occurring in June. During summer the larvae live and feed gregariously and spin a silken web around the plantain leaves. They enter diapause within the web during early autumn, and emerge the following spring, when they again feed communally and spin a conspicuous web around plantains before pupating in April.

The Glanville fritillary is highly conducive for research and monitoring, principally because the larvae form conspicuous 'webs', making it possible to conduct accurate population counts within just a couple of weeks each year (Thomas \& Simcox 1982). As a monophagous species with limited distribution and narrow niche breadth the Glanville fritillary is predicted to be extremely sensitive to climate change (Diamond et al. 2011).

In this paper, we describe the population dynamics of the UK Glanville fritillary population across eight sites from 18 years of monitoring data. We combine our data with adults counts from five transects of the UK Butterfly Monitoring Scheme, to produce a synthetic overview of the status of this species on the Isle of Wight. These sites harbour the bulk of the British population of this species, so our results define the national conservation status of this species, which is one of the rarest in the UK.

\section{Methods}

A survey of Glanville fritillary larval webs in 1979 (Simcox \& Thomas 1979) repeated in 1996 (Thomas et al. 2001) established that over 95\% of the British population occurred on eight sites along the south coast of the Isle of Wight (see Figure 1 and Table 1), between Compton Bay in the west, and Red Cliff at the south-eastern end of the Island.

Four of these sites (Brook, Chilton, Grange and Shepherds) are centred on chines or riverine valleys, where small land slippages and erosion produce patches of bare ground that are ideal breeding 
habitat for Glanville fritillaries. Compton and Red Cliff comprise large areas of rapidly-eroding cliffs characterised by frequent landslips, creating a dynamic patchwork of suitable and unsuitable habitat patches. Finally, two sites (St Catherine's Point and Binnel Point) are semi-permanent grassland.

The abundance of Glanville fritillary has been monitored at these sites annually since 1996. All sites were surveyed every year, except Brook (1997 and 2001) and Chilton (2001). Surveys were conducted during March, which is when the larval webs are largest and most conspicuous (Simcox \& Thomas 1979). Abundance was calculated as the total number of larval 'webs', which were counted by walking briskly along a series of survey lines spaced 5 metres apart until the entire area had been surveyed. Webs were recorded within an area of approximately 2.5 metres square, as per the transect methods used for adult butterflies (Pollard \& Yates 1993; Botham et al. 2009).

We also extracted counts of adult Glanville fritillaries from the UKBMS dataset for the five transect routes on the Isle of Wight. Whilst adult Glanville fritillaries are occasionally recorded on transects on the English mainland, it is widely suspected that most are introduced populations that are supplemented by collectors, so the index for these sites is unlikely to reflect natural population dynamics. We also excluded counts from the Channel Islands, as these are not in the U.K. We constructed separate collated population indices (Pollard \& Yates 1993) from the eight web count sites in this study and the five transects with adult counts, as well as a combined index for the whole island, with all 13 sites together.

\section{Results}

Populations fluctuated considerably over the 18 years of the survey (note the log scale on Figure 2). However, some sites are clearly much more variable than others (Table 1). A variance components analysis reveals strong synchrony across sites, with over 2.5 times as much variance among years as among sites. In 2013 the population appeared to go extinct at five sites, and fell to historically low levels at the other three (Figure 2). Prior to 2013 there were just three extinction events: at two of these the population returned the following year but Red Cliff (the most isolated site) remained unoccupied between 2000 and 2005 .

A collated index based on adult counts (UKBMS transects) was not possible every year (figure 3), since the number of sites is small and not all were surveyed in all years. At four of the five sites, Glanville fritillaries were observed in a minority of survey years: three of these are in the northern part of the Isle of Wight and the butterflies seen here probably represent transient individuals rather than breeding populations. Not surprisingly, the collated index for our eight sites shows 2013 as the lowest overall abundance since the survey began in 1996 (figure 3). The whole island index is almost 
indistinguishable from the index based on our eight sites, reflecting the larger number of contributory sites and the fact that adult Glanville Fritillaries are generally recorded at low numbers on UKBMS transects. The overall trajectory of larval and adult-based indices is broadly similar, with a steep increase during 2008-9 followed by a sharp decline in 2012-3 (figure 3).

\section{Discussion}

Our results reveal wide fluctuations in Glanville Fritillary abundance, both on web count sites (figure 2) and the sites where adults are counted (figure 3). Thus, there are 'boom' years, where the population increases dramatically, but these are followed by 'bust'. Boom years are clearly identifiable as 1997, 2006/7 and 2010, with bust years in 2003, 2008 and 2013.

\section{Thermophily and boom-bust dynamics}

The British population of Glanville fritillary is at the very edge of its thermal tolerance. Its hostplant is widespread, but its distribution is restricted to the warmest microclimate (early-successional habitat) on south-facing slopes in one of the warmest parts of the country (Thomas 1993).

The preference for warmer hostplants and earlier successional stages can be understood by examining the larval ecology, and particularly the reliance on effective thermoregulation (Thomas 1991). Glanville fritillary larvae are gregarious until the final instars: this behaviour is more effective at raising body temperature than basking individually (Porter 1982; Bryant et al. 2000). Glanville fritillary larvae are able to raise their body temperature by up to 20 degrees Celsius above ambient, at which point larvae leave the web to feed on the surrounding plantains (Thomas \& Lewington 2010). The body temperature of a caterpillar then falls sharply, so larvae feed in short bouts between basking. This post-feeding basking is believed to be important in maximising the efficiency of a gut enzyme (J. Thomas pers comm). Thus, microclimatic temperature is crucial for the metabolism and development of Glanville fritillary larvae.

Adult females select hostplants that provide the warmest microhabitats (Thomas et al. 2001; Curtis \& Isaac 2014), in order to maximise thermoregulation and metabolic efficiency, thus expediting development time (Bryant et al. 2002). Furthermore, fast larval development may also be important to minimise the risk of attack from host specific parasitoids, as synchronicity between parasitoid and host is much greater during cooler years (van Nouhuys \& Lei 2004). However, parasitism had minimal impacts on population dynamics on the Aland Islands (Hanski \& Meyke 2005), and our data support a similar interpretation: populations at Red Cliff and Binnel Point are highly synchronous 
(figure 2), despite the parasitoid occurring on the latter site only since 2005 (Curtis, unpublished data).

Microclimate is partly determined by ambient temperature (i.e. weather), which means that not all hostplants are suitable for oviposition in all years. In years when June is relatively cold, only a small subset of plantains are used for oviposition, but in warmer years the females will lay eggs on plants on cooler aspects (Davies et al. 2006) and slopes (Weiss et al. 1988). This leads to a strong correlation between June temperature and the number of webs the following March (Curtis \& Isaac 2014). The larvae are voracious feeders in the final instars, at which stage they are large enough to individually thermoregulate and thus feed without the need for gregarious basking. In years of high larval density, it is common for sites to be stripped bare of plantains in April. These same larvae then emerge in May on a site with few plantains on which to lay eggs. We speculate that this scenario creates strong density dependence and leads to population crashes the following year. It's not clear whether the primary mechanism is female dispersal in search of alternate (but nonexistent) egglaying habitat, or larval mortality through competition for scarce food resources. Regardless of the mechanism involved, it seems clear that the boom-bust dynamics we observe are a consequence of extreme thermophily and the patchy nature of the breeding habitat.

The boom-bust dynamics we observe in the Glanville fritillary are consisted with other butterflies at northern limits of their range (Thomas et al. 1994). The amplitude of fluctuation for many British species has dampened in recent decades, as the climate has warmed (Oliver et al. 2012): if anything, the fluctuations in Glanville fritillary appear to be getting more extreme (Figure 2), in spite of a strong warming trend on the Isle of Wight (Figure 4).

\section{Demise or Conservation?}

The 2013 survey within the eight core sites showed widespread synchronous dramatic declines. This pattern was mirrored on the UKBMS transect routes (Figure 3), suggesting that the Isle of Wight population is at its lowest recorded level, with the total area used for breeding no more than a few $\mathrm{km}^{2}$. Our results highlight the urgent need for a more wide-ranging survey of the butterfly on the Isle of Wight to determine current status and assess any extent to which the butterfly has shifted local distribution due to changing habitat conditions.

While the boom - bust nature of population dynamics exhibited by this species would suggest that recovery is possible, it could take many years to recolonize all of the former range. Indeed, the 2000 extinction at Red Cliff, which is the most isolated of the eight monitored sites, took five years to be 
recolonized (Figure 2). What, then, are the prospects for the long-term survival of the species in Britain?

Most of the known sites occur on soft cliff habitats where few management options are available. Two sites, St Catherine's and Binnel Point, are characterised by semi-permanent grassland, on which management is possible through grazing. The majority of St Catherine's Point is overgrazed, and most of the suitable habitat lies within a small livestock exclosure where the sward height is at risk of becoming too long for oviposition. Binnel Point is a very small site, where tamarisk is encroaching onto the suitable breeding habitat: recent control efforts have been linked to increasing erosion.

We are aware of at least one other population which is not included in this survey, at Wheeler's Bay near Ventnor. Much of the breeding area is on an escarpment, which is impossible to survey without climbing equipment. However, counts from the base of the escarpment suggest that Wheeler's Bay is an important population (A.Butler pers comm). In the west of the Island there are extensive areas of chalk downland around Afton and Compton, which contain large areas of potentially suitable habitat. This area includes the UKBMS transect at Mottistone Down, where just three adult Glanville fritillaries were observed in 2013 (UKBMS 2013). Larval webs have been observed intermittently in this area (RJC, pers obs) and it's possible that small colonies persist here.

Our review of sites known to recently support Glanville Fritillary on the island, suggest there is no single change in habitat or land management that is causing decline, whilst the strong degree of synchrony in annual change implicates climate as a factor. Once a census has been carried out to determine the location and size of all remaining populations, further research is required to fully understand the causes of decline, so that a recovery plan can be formulated.

The prospects for the butterfly away from the Island look bleak. On the mainland, Glanville populations have occurred at Hurst Castle in Hampshire (close to the Isle of Wight) and at Sand Point in Somerset, in addition to scattered sightings elsewhere in southern England. The Glanville is known to have been subject to numerous unauthorized introductions (Asher et al. 2001) and it's likely these populations are not self-sustaining but a result of frequent supplementation.

The Glanville fritillary has always been one of Britain's rarest breeding butterflies, but our results indicate that it is vulnerable to extinction in its stronghold sites on the Isle of Wight. Even if the numbers can be stabilised in the short term and unoccupied sites recolonized, the Glanville will always carry a high intrinsic risk of extinction in Britain. Indeed, it could be seen as an archetype of the small population paradigm in conservation biology (Caughley 1994), as it suffers from the triple whammy of few occupied sites, large fluctuations in abundance and synchronous population 
dynamics across sites. In addition, the possible erosion of genetic diversity and changing climate present extrinsic threats to future persistence. Whilst the future is highly uncertain, it's not too late to act.

\section{Acknowledgements}

This work as supported by NERC grants NE/D009448/1 and NE/F007930/1. We are also grateful to the Isle of Wight Natural History and Archaeological Society (IWNHAS), Andy Butler, David Simcox, Jeremy Thomas, Wightlink and two anonymous reviewers.

\section{References}

Andrewartha H.G. \& Birch L.C. (1954). Distribution and abundance of animals. University of Chicago Press, Chicago.

Asher J., Warren M., Fox R., Harding P., Jeffcoate G. \& Jeffcoate S. (2001). The Millennium Atlas of Butterflies in Britain and Ireland. Oxford University Press., Oxford.

Begon R., Harper J.L. \& Townsend C.R. (1986). Ecology - Individuals, Populations and Communities. Blackwell, Oxford.

Botham M.S., Brereton T.M., Middlebrook I., Cruickshanks K.L., Zannese A. \& Roy D.B. (2009). United Kingdom Butterfly Monitoring Scheme report for 2009. In. CEH Wallingford.

Brown J.H. (1984). The relationship between abundance and distribution of species. American Naturalist, 124, 255-279.

Bryant S.R., Thomas C.D. \& Bale J.S. (2000). Thermal ecology of gregarious and solitary nettle-feeding nymphalid butterfly larvae. Oecologia, 122, 1-10.

Bryant S.R., Thomas C.D. \& Bale J.S. (2002). The influence of thermal ecology on the distribution of three nymphalid butterflies. Journal of Applied Ecology, 39, 43-55.

Caughley G. (1994). Directions in conservation biology. Journal of Animal Ecology, 215-244.

Curtis R.J. \& Isaac N.J.B. (2014). The Effect of Temperature and Habitat Quality on Abundance of the Glanville fritillary on the Isle of Wight; Implications for Conservation Management in a Warming Climate. Journal of Insect Conservation, In review.

Davies Z.G., Wilson R.J., Coles S. \& Thomas C.D. (2006). Changing habitat associations of a thermally constrained species, the silver-spotted skipper butterfly, in response to climate warming. Journal of Animal Ecology, 75, 247-256.

Dennis R.L.H. (2010). A Resource-Based Habitat View for Conservation: Butterflies in the British Landscape. Wiley - Blackwell, Chichester, UK.

Diamond S.E., Frame A.M., Martin R.A. \& Buckley L.B. (2011). Species' traits predict phenological responses to climate change in butterflies. Ecology, 92, 1005-1012.

Ehrlich P.R. (1983). Genetics and the extinction of butterfly populations. In: Genetics and Conservation. A reference for Managing Wild Animal and Plant Populations. (eds. Schonewald Cox CM \& Chambers SM, MacBryde, B. and Thomas, W.L.). Benjamin/Cummings Publishing Company. California.

Erhardt A. \& Thomas J.A. (1991). Lepidoptera as indicators of change in semi-natural grasslands of lowland and upland Europe. In: The Conservation of Insects and their Habitats. (eds. Collins NM \& Thomas JA). Academic Press London, pp. 213-236.

Ford E.B. (1945). Butterflies. Collins., London.

Hanski I. (1994). A Practical Model of Metapopulation Dynamics. Journal of Animal Ecology, 63, 151162.

Hanski I. (1998). Metapopulation dynamics. Nature, 396, 41-49. 
Hanski I. (1999). Metapopulation Ecology. Oxford University Press, Oxford.

Hanski I. \& Meyke E. (2005). Large-scale dynamics of the Glanville fritillary butterfly: landscape structure, population processes, and weather. Annales Zoologici Fennici, 42, 379-395.

Johst K., Drechsler M., van Teeffelen A.J.A., Hartig F., Vos C.C., Wissel S., Waetzold F. \& Opdam P. (2011). Biodiversity conservation in dynamic landscapes: trade-offs between number, connectivity and turnover of habitat patches. Journal of Applied Ecology, 48, 1227-1235.

Jones J.P.G. (2011). Monitoring species abundance and distribution at the landscape scale. Journal of Applied Ecology, 48, 9-13.

Krebs C., J (1978). Ecology: The Experimental Analysis of Distribution and Abundance. Harper \& Row, New York.

Leidner A.K. \& Haddad N.M. (2011). Combining Measures of Dispersal to Identify Conservation Strategies in Fragmented Landscapes. Conservation Biology, 25, 1022-1031.

MacArthur R. (1984). Geographical ecology: patterns in the distribution of species. Princeton University Press.

Mattila N., Kaitala V., Komonen A., PÄlvinen J. \& Kotiaho J.S. (2011). Ecological correlates of distribution change and range shift in butterflies. Insect Conservation and Diversity, 4, 239246.

May R.M. (1975). Patterns of species abundance and diversity. In: Ecology and evolution of communities (ed. Cody MLD, J.M.). The Belknap Press of Harvard University Press Cambridge, MA, pp. 81 - 120.

McGill B.J. (2006). A renaissance in the study of abundance. Science, 314, 770-772.

Ojanen S.P., Nieminen M., Meyke E., Pöyry J. \& Hanski I. (2013). Long-term metapopulation study of the Glanville fritillary butterfly (Melitaea cinxia): survey methods, data management, and long-term population trends. Ecology and Evolution, 3, 3713-3737.

Oliver T.H., Roy D.B., Brereton T. \& Thomas J.A. (2012). Reduced variability in range-edge butterfly populations over three decades of climate warming. Global Change Biology, 18, 1531-1539.

Oostermeijer J.G.B. \& van Swaay C.A.M. (1998). The relationship between butterflies and environmental indicator values: a tool for conservation in a changing landscape. Biological Conservation, 86, 271-280.

Pollard E. \& Yates T.J. (1993). Monitoring Butterflies for Ecology and Conservation. Chapman and Hall, London.

Porter K. (1982). Basking behaviour in larvae of the butterfly Euphydryas aurinia. Oikos, 308-312.

Ross J.V., Sirl D.J., Pollett P.K. \& Possingham H.P. (2008). Metapopulation persistence in a dynamic landscape: More habitat or better stewardship? Ecological Applications, 18, 590-598.

Roy D.B., Rothery P. \& Brereton T. (2007). Reduced-effort schemes for monitoring butterfly populations. Journal of Applied Ecology, 44, 993-1000.

Simcox D.J. \& Thomas J.A. (1979). The Glanville fritillary survey 1979. In: Unpublished report to the Joint Committee for the Conservation of British Insects. Furzebrook, Dorset.

Storch D. \& Gaston K.J. (2004). Untangling ecological complexity on different scales of space and time. Basic and Applied Ecology, 5, 389-400.

Thomas J.A. (1991). Rare species conservation: Case studies of European butterflies. In: The Scientific Management of Temperate Communities for Conservation (eds. Spellerberg IF, Goldsmith FB \& G. MM). Blackwell Oxford, pp. 149 - 197.

Thomas J.A. (1993). Holocene climate changes and warm man-made refugia may explain why a 6th of British butterflies possess unnatural early-successional habitats. Ecography, 16, 278-284.

Thomas J.A. (1995). Why Small Cold-Blooded Insects Pose Different Conservation Problems to Birds in Modern Landscapes. Ibis, 137, S112-S119.

Thomas J.A., Bourn N.A.D., Clarke R.T., Stewart K.E., Simcox D.J., Pearman G.S., Curtis R. \& Goodger B. (2001). The quality and isolation of habitat patches both determine where butterflies persist in fragmented landscapes. Proceedings of the Royal Society of London Series BBiological Sciences, 268, 1791-1796. 
Thomas J.A. \& Lewington R. (2010). The butterflies of Britain \& Ireland. British Wildlife Pub., Gillingham.

Thomas J.A., Moss D. \& Pollard E. (1994). Increased Fluctuations of Butterfly Populations Towards the Northern Edges of Species Ranges. Ecography, 17, 215-220.

Thomas J.A. \& Simcox D.J. (1982). A quick method for estimating larval populations of Melitaea cinxia L. during surveys. Biological Conservation, 22, 315-322.

Thomas J.A., Telfer M.G., Roy D.B., Preston C.D., Greenwood J.J.D., Asher J., Fox R., Clarke R.T. \& Lawton J.H. (2004). Comparative losses of British butterflies, birds, and plants and the global extinction crisis. Science, 303, 1879-1881.

UKBMS (2013). Mottistone Down: Counts for the year 2013. URL http://www.ukbms.org/SiteListbyYear.aspx?siteld=129\&year=2013

van Nouhuys S. \& Lei G.C. (2004). Parasitoid-host metapopulation dynamics: the causes and consequences of phenological asynchrony. Journal of Animal Ecology, 73, 526-535.

Weiss S.B., Murphy D.D. \& White R.R. (1988). Sun, Slope, and Butterflies: Topographic Determinants of Habitat Quality for Euphydryas editha. Ecology, 69, 1486-1496.

Whittaker R.H. (1975). Communities and Ecosystems. Macmillan, New York. 
Table 1: Summary statistics on population time series for each site. Sites are listed from west to east.

$\begin{array}{llrl} & \begin{array}{l}\text { Ordnance } \\ \text { Survey grid } \\ \text { Site name }\end{array} & \begin{array}{l}\text { Mean } \\ \text { reference }\end{array} & \begin{array}{l}\text { Count } \\ \text { coefficient of } \\ \text { variation }\end{array} \\ \text { Brook } & \text { SZ371848 } & 102.3 & 1.05 \\ \text { Chilton } & \text { SZ387831 } & 75.2 & 1.05 \\ \text { Grange } & \text { SZ410821 } & 127.9 & 1.01 \\ \text { Shepherd's Chine } & \text { SZ421817 } & 123.7 & 1.27 \\ \text { St Catherine's Point } & \text { SZ499753 } & 156.6 & 0.83 \\ \text { Binnel Point } & \text { SZ525758 } & 32.1 & 1.64 \\ \text { Red Cliff } & \text { SZ620854 } & 17.8 & 1.45\end{array}$


Figure 1. A map of study sites on the Isle of Wight.

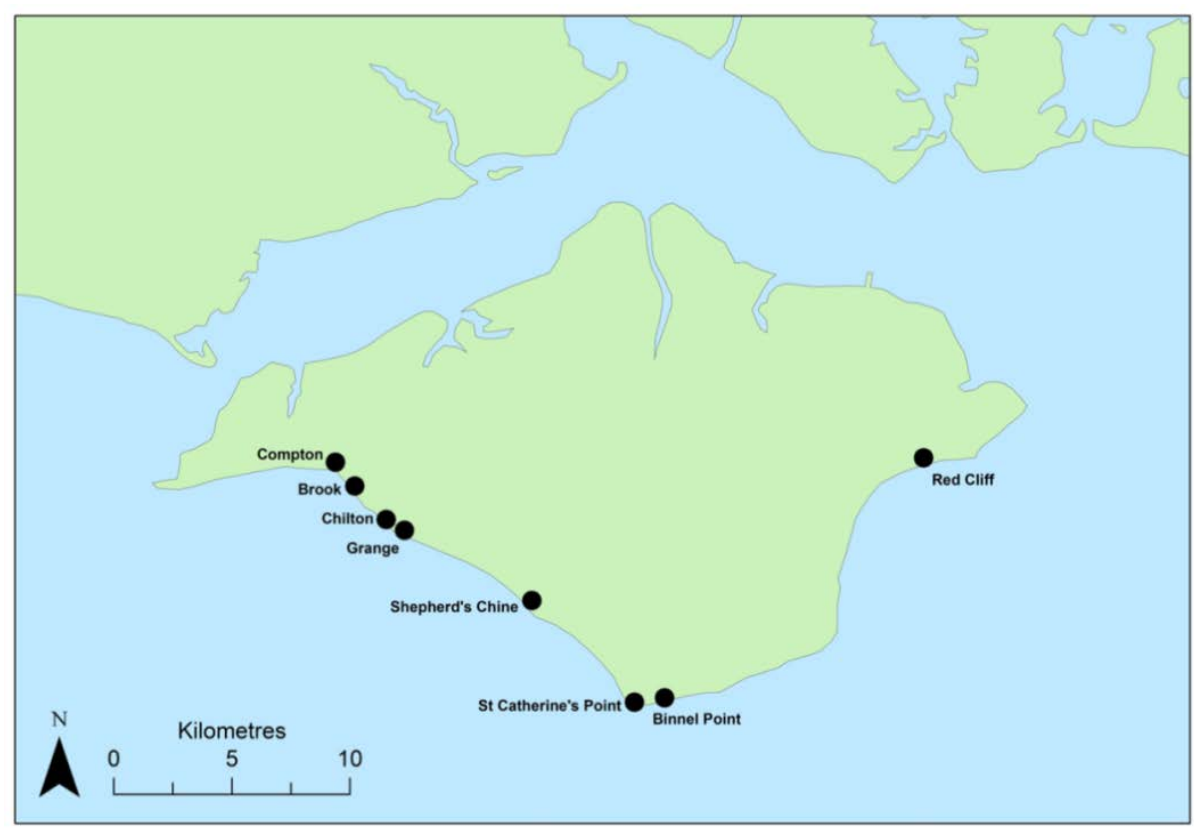


Figure 2. Larval web counts for Glanville Fritillary at eight sites, 1996-2013.

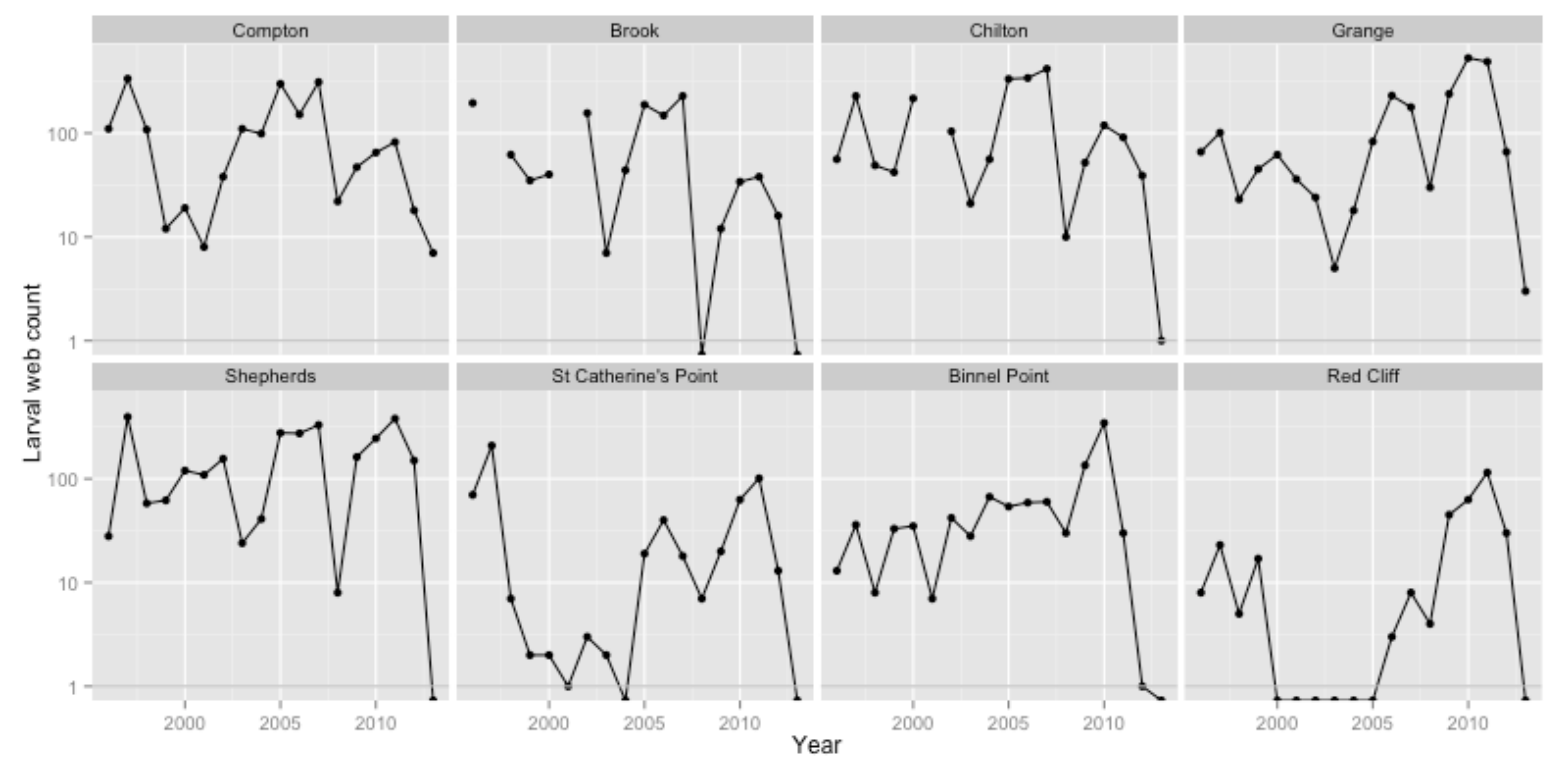


Figure 3. Collated population indices for the Glanville Fritillary on the Isle of Wight.

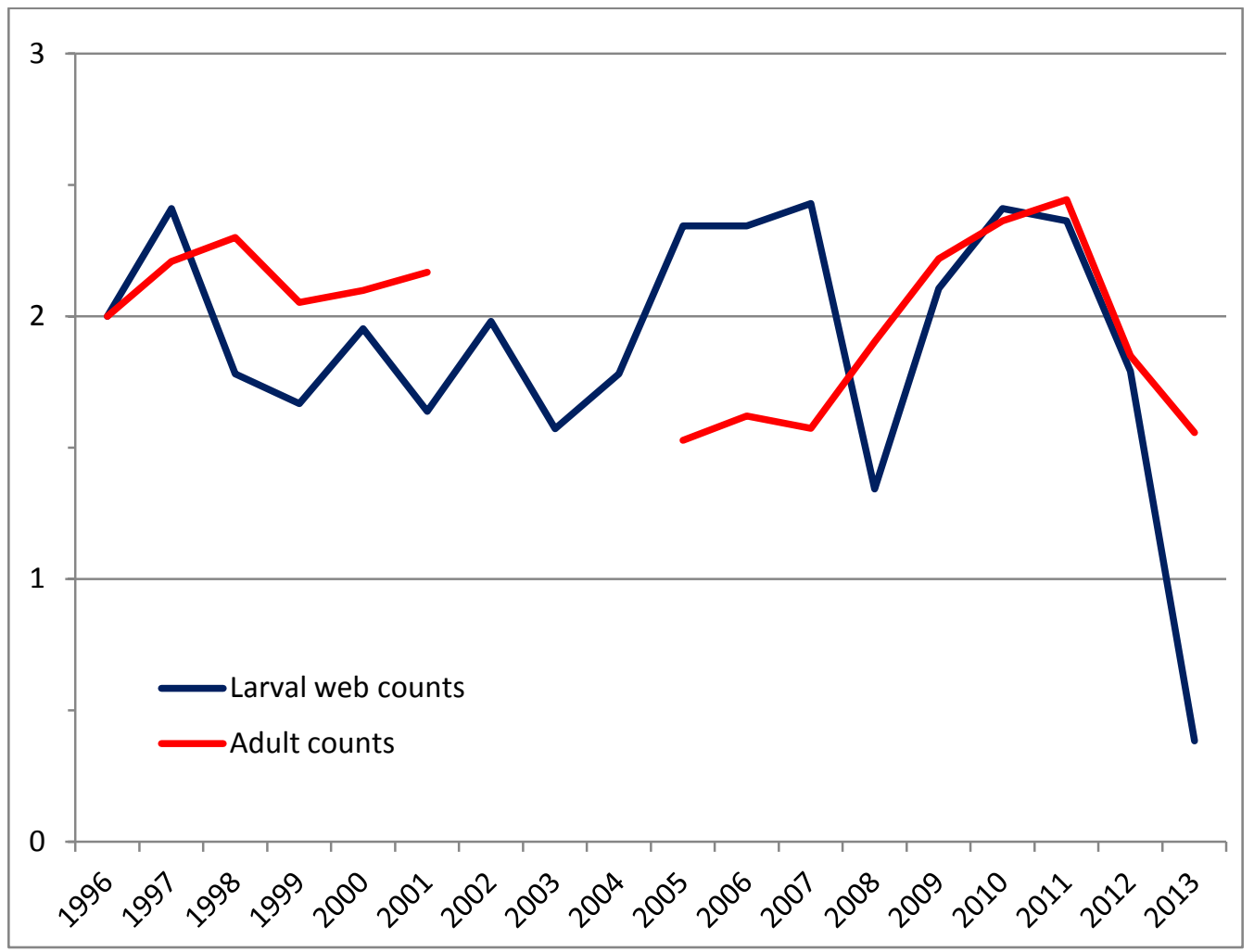


Figure 4. June mean maximum temperatures from 1997 - 2010 at St Catherine's Point lighthouse, Isle of Wight, with least squares regression line.

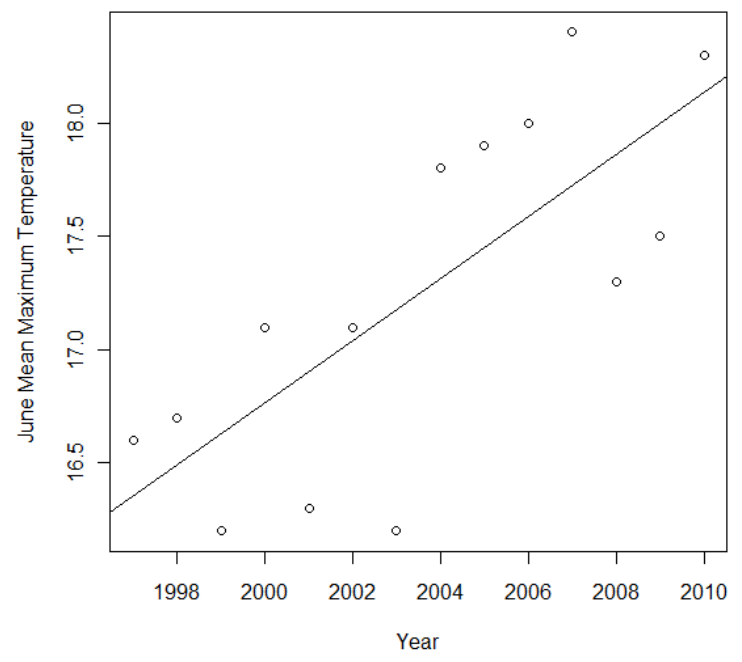

